Dated: September 20, 2012. Jared Blumenfeld,

Regional Administrator, Region IX.

Therefore, 40 CFR chapter I is amended as follows:

\section{PART 52-[AMENDED]}

a 1 . The authority citation for part 52 continues to read as follows:

Authority: 42 U.S.C. 7401 et seq.

\section{Subpart F-California}

2. Section 52.220 is amended by adding and reserving paragraph (c)(417) and adding paragraph (c)(418) to read as follows:

\section{$\$ 52.220$ Identification of plan. \\ * * * * * \\ (c) ***}

(417) [Reserved]

(418) New and amended regulation for the following APCD was submitted on April 22, 2011, by the Governor's Designee.

(i) Incorporation by Reference

(A) South Coast Air Quality

Management District

(1) Rule 317, "Clean Air Act Non-

Attainment Fees," amended on

February 4, 2011.

[FR Doc. 2012-29385 Filed 12-13-12; 8:45 am] BILLING CODE 6560-50-P

\section{ENVIRONMENTAL PROTECTION AGENCY}

\section{CFR Part 82}

[EPA-HQ-OAR-2011-0111; FRL-9757-5]

RIN 2060-AQ84

\section{Protection of Stratospheric Ozone: Listing of Substitutes for Ozone Depleting Substances-Fire Suppression and Explosion Protection}

AGENCY: Environmental Protection Agency (EPA).

ACTION: Withdrawal in part of direct final rule.

SUMmARY: On September 19, 2012, the Federal Register published a direct final rule and a companion proposed rule issuing listings for three fire suppressants under EPA's Significant New Alternatives Policy program. Because EPA received adverse comment concerning C7 Fluoroketone, we are withdrawing that part of the direct final rule that listed C7 Fluoroketone acceptable subject to narrowed use limits as a substitute for halon 1211. Other listings in that direct final rule will take effect on December 18, 2012.
DATES: Effective December 14, 2012, EPA withdraws the entire entry for "Streaming: C7 Fluoroketone as a substitute for Halon 1211" in Appendix S to Subpart G of Part 82 in the direct final rule published at 77 FR 58035 , September 19, 2012. FOR FURTHER INFORMATION CONTACT:

Bella Maranion, Stratospheric

Protection Division, Office of Atmospheric Programs; Environmental Protection Agency, Mail Code 6205J, 1200 Pennsylvania Avenue NW., Washington DC 20460; telephone number (202) 343-9749, fax number, (202) 343-2338; email address at maranion.bella@epa.gov. The published versions of notices and rulemakings under the SNAP program are available on EPA's Stratospheric Ozone Web site at http://www.epa.gov/ozone/snap/regs. SUPPLEMENTARY INFORMATION: On September 19, 2012, the Federal Register published a direct final rule and a companion proposed rule issuing listings for three fire suppressants under EPA's Significant New Alternatives Policy program (77 FR 58035). Because EPA received adverse comment concerning C7 Fluoroketone, we are withdrawing that part of the direct final rule that listed C7 Fluoroketone.

The listing would have found $\mathrm{C} 7$ Fluoroketone acceptable subject to narrowed use limits, as a substitute for halon 1211 for use as a streaming agent in portable fire extinguishers in nonresidential applications. We stated in that direct final rule that if we received adverse comment by October 19,2012 , that we would publish a timely withdrawal in the Federal Register. We subsequently received one adverse comment on that part of the direct final rule, but no comments on the other listings in the direct final rule. The other listings in that direct final rule, finding Powdered Aerosol $\mathrm{F}$ and Powdered Aerosol G acceptable subject to use conditions as substitutes for halon 1301 for use as a total flooding agent in normally unoccupied areas, will take effect on December 18, 2012. EPA intends to address the adverse comment concerning C7 Fluoroketone in a subsequent final action, which will be based on the parallel proposed rule published on September 19, 2012 (77 FR 58081). As stated in the direct final rule and the parallel proposed rule, we will not institute a second comment period on this action.

Dated: December 5, 2012.

Gina McCarthy,

Assistant Administrator, Office of Air and Radiation.

Accordingly, the entire entry for "Streaming: C7 Fluoroketone as a substitute for Halon 1211"' in Appendix $S$ to Subpart G of Part 82 in the direct final rule published on September 19, 2012 (77 FR 58035) is withdrawn as of December 14, 2012.

[FR Doc. 2012-29984 Filed 12-13-12; 8:45 am] BILLING CODE 6560-50-P

\section{DEPARTMENT OF HEALTH AND HUMAN SERVICES}

\section{Centers for Medicare \& Medicaid Services}

42 CFR Parts 438, 441, and 447

[CMS-2370-CN]

RIN 0938-AQ63

\section{Medicaid Program; Payments for Services Furnished by Certain Primary Care Physicians and Charges for Vaccine Administration Under the Vaccines for Children Program; Correction}

AGENCY: Centers for Medicare \& Medicaid Services (CMS), HHS. ACTION: Final rule; correction.

SUMMARY: This document corrects technical errors that appeared in the final rule published in the November 6, 2012 Federal Register entitled

"Medicaid Program; Payments for Services Furnished by Certain Primary Care Physicians and Charges for Vaccine Administration under the Vaccines for Children Program."

DATES: Effective Date: The provisions of this final rule are effective on January 1 , 2013.

FOR FURTHER INFORMATION CONTACT: Mary Cieslicki, (410) 786-4576, or Linda Tavener, (410) 786-3838, for issues related to payments for primary care physicians.

Mary Beth Hance, (410) 786-4299, for issues related to charges for the administration of pediatric vaccines. SUPPLEMENTARY INFORMATION:

\section{Background}

In FR Doc. 2012-26507 of November 6, 2012 (77 FR 66670), there were a number of technical errors that are identified and corrected in the Correction of Errors section below. The provisions in this correction document are effective as if they had been included in the document published November 6, 2012. Accordingly, the corrections are effective January 1, 2013.

\section{Summary of Errors}

In the November 6, 2012 final rule (77 FR 66670), we inadvertently published 